\title{
「電力系統へのパワエレ機器適用の新展開——系統解析, 運用，制御の側面から—」」特集号によせて
}

\author{
大山 力
}

横浜国立大学

最近の電カシステム分野の進歩はパワーエレクトロニク ス技術に負うところが多いことは周知のことであろう。従 来は(といってもかなり昔のことになってしまうが) 回転機 と送電系統が本来備えている安定性に頼らざるを得なかっ たような短い時間領域でも、パワーエレクトロニクス機器 が導入されることにより積極的な制御が可能となってきた。

日本においては東西両系統で周波数が50へルツと60へ ルツに分かれていることもあり、パワーエレクトロニクス を使った周波数変換設備が活用されている。また、北海道と 本州の海峡を結ぶ北本直流送電設備も大いに活躍している。 さらに、紀伊水道直流送電設備、中部-北陸電力間の非同期 連采設備（あいだに直流区間を挟むことにより、潮流制御の 自由度を増す)等、大規模なパワーエレクトロニクス設備が 建設、導入されている。

また、SVC やFACTS機器、可変速場水発電機も系統人 の導入が行われており、基幹系統の安定性、運用の自由度を 高めるのに一役買っている。

需要地近傍に目を向けると、分散型発電にもパワーエレ クトロニクス機器は利用されている。太陽電池や燃料電池 等の分散型電源、 $\mathrm{NaS}$ 電池等の分散型貯蔵装置は基本的に 直流を発生する機器であるため、パワーエレクトロニクス 技術を使ったインバータ/コンバータを使わなければ従来 の系統に連系する事はできない。最近話題のマイクロガス タービンも系統連系のためにはパワーエレクトロニクス機 器による周波数変換のお世話になっている。

さらに電気利用の分野でもインバータが多用されている のが実状である（これは負荷特性を変化させることから電 カシステムにとっては歓迎できない面もあるが)。いずれに しても、電力システムの上流から下流まで、あらゆるところ でパワーエレクトロニクスが使われている。

このようにパワーエレクトロニクスが多用されているこ とを考えると、一つ一つの機器の導入による効果を考える だけでは不十分である。多数のパワーエレクトロニクス機 器がどのように相互作用するかまで考える必要がある。そ の意味で、パワーエレクトロニクス機器の電カシステムへ の適用は新しい局面を迎えているといって良いだろう。
本特集はそのような状況をふまえて企画されたものであ る。論文募集時にあげられていたトピックとしては、 ・パワエレ機器を含む電力系統の新しい解析手法 ・パワエレ機器を含む系統全体の経済性、供給信頼性向上の ための運用・制御手法

・パワエレ機器と系統全体の運用・制御を協調させた経済 性、供給信頼性の評価手法

・複数のパワエレ機器間を協調させた制御方式

・パワエレ機器の系統への導入効果の評価手法

・規制緩和下でのパワェレ機器の導入効果

・パワエレ機器導入を前提とした送電および配電系統の新し いコンセプト

等があった。

この特集に対して投稿された論文数は15件であった。本 稿執筆時点では何件の論文が採択されて本号に揭載される かはわかっていないが、バラエティに富んだ論文が掲載さ れることになることが期待できる。

投稿された論文の内容は、やはり采統安定化に関するも のが最も多いようである。短い時間領域での系統制御にパ ワーエレクトロニクス機器が欠かせない現状を考えると、 これは当然かもしれない。

次に多かったのが、送配電系統の新しいコンセプトに関 するものである。この分野は(新しいコンセプトなので当然 だが）現在実用化されている技術ではない。しかし、将来の 電カシステムのあり方を探る上で大変重要な分野であるこ とは間違いない。電カシステム分野の研究に新風を吹き込 むためにもこの分野の研究が活発化することが望まれる。

パワエレ機器と系統全体の協調や複数のパワエレ機器間 の協調を扱った論文は残念ながら多くはなかった。しかし、 この問題はこれからますます重要になってくるものと考え られる。そのような分野を含め、パワエレ機器の適用に関す る多方面の研究が本特集を契機にますます盛んとなること を望むものである。

(平成 12 年 5 月 9 日受付)

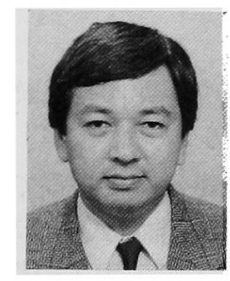

大山 力 (正員) 1983年3月東京大学大学院 博士課程修了。工学博士。83年4月より横浜国 立大学講師。85年10月同助教授。98年 4 月同 教授。87年より89年まで米国テキサス大学アー リントン校客員助教授。主として電カシステム の解析、計画、運用に関寸る研究に従事。

Preface to Special Issue on New Trend in Application of Power Electronics Apparatus to Power System.

By Tsutomu Oyama (Yokohama National University) 